\title{
DETERMINANTS OF WOMEN'S PREFERENCE FOR CESAREAN SECTION
}

\author{
Fernanda Hannah da Silva Copelli ${ }^{1}$ Larissa Rocha², Maria de Fátima Mota Zampieri ${ }^{3}$, Vitória Regina Petters \\ Gregório ${ }^{4}$ Zaira Aparecida de Oliveira Custódio ${ }^{5}$
}

\footnotetext{
${ }^{1}$ Master's Degree student in Nursing by the Graduate Program in Nursing of the Universidade Federal de Santa Catarina (UFSC). Florianópolis, Santa Catarina, Brazil. E-mail: fernandacopelli@hotmail.com

2 Master's Degree student in Nursing by the Graduate Program in Nursing of UFSC. Florianópolis, Santa Catarina, Brazil. E-mail: enfa.larissa.rocha@gmail.com

${ }^{3}$ Ph.D. in Nursing. Professor of the Department of Nursing of UFSC. Florianópolis, Santa Catarina, Brazil. E-mail: mfatima@ nfr.ufsc.br

${ }^{4}$ Ph.D. in Nursing. Professor of the Department of Nursing of UFSC. Florianópolis, Santa Catarina, Brazil. E-mail: vitoriarpg@ gmail.com

5 Ph.D. in Psychology. Psychologist at the University Hospital of UFSC. Florianópolis, Santa Catarina, Brazil. E-mail: zaira@ hu.ufsc.br
}

\begin{abstract}
A qualitative, exploratory, descriptive, documentary, and retrospective research study to identify the determinants of women's preference for cesarean section. The information in this study is from the database extension project Group of Pregnant Women and Pregnant Couples by the Universidade Federal de Santa Catarina (1996-2013). We used the method of thematic analysis, from which emerged the Choice for Cesarean Section category, with three subcategories: who chooses cesarean section; preference for cesarean section defined during prenatal care; and possibility to choose cesarean section during labor. Of 169 postpartum women who had undergone a cesarean section, 16 chose the procedure. It was found that, in this group, the choice for cesarean section during prenatal care was influenced by the medical authority and, during labor, it was motivated by the prolonged duration and the pain caused by contractions. This study reinforced the importance of health education from the time of conception, and highlighted the need to strengthen public policies that increase the potential of women to make choices.
\end{abstract}

DESCRIPTORS: Health education. Postpartum period. Cesarean section. Public policies.

\section{FATORES DETERMINANTES PARA A PREFERÊNCIA DA MULHER PELA CESARIANA}

RESUMO: Pesquisa qualitativa, exploratório-descritiva, documental, retrospectiva, com objetivo de conhecer os fatores determinantes para a preferência da mulher pela cesariana. As informações desta investigação pertencem ao banco de dados do projeto de extensão Grupo de Gestantes e Casais Grávidos da Universidade Federal de Santa Catarina (1996-2013). Utilizou-se o método de análise temática, do qual emergiu a categoria Opção pela cesariana, com três subcategorias: Quem opta pela cesariana?; Preferência pela cesariana definida no prénatal; e Alternativa da cesariana durante o trabalho de parto. Das 169 puérperas submetidas à cesariana, 16 optaram pelo procedimento. Verificou-se, nesse grupo, que a escolha da cesariana no pré-natal sofreu influência do poder médico e, no trabalho de parto, foi motivada pela duração "prolongada" e pela dor oriunda das contrações. Este estudo reforçou a importância da educação em saúde desde a gestação e destacou a necessidade de consolidar políticas públicas, que fortaleçam o potencial da mulher para fazer escolhas.

DESCRITORES: Educação em saúde. Período pós-parto. Cesárea. Políticas públicas.

\section{DETERMINANTES PARA LA PREFERENCIA DE LAS MUJERES POR CESÁREA}

RESUMEN: Cualitativo, exploratorio, descriptivo, documental y retrospectivo, con el fin de conocer los factores determinantes de la preferencia de las mujeres por factores cesárea. La información contenida en esta investigación pertenecen al Grupo de mujeres embarazadas y parejas embarazadas base de datos del Proyecto de Extensión de la Universidade Federal de Santa Catarina (1996-2013). Se utilizó el método de análisis temático, de la que surgió la Opción por cesárea categoría, con tres subcategorías: ¿Quién opta por cesárea; Preferencia por cesárea se define en la atención prenatal; y Alternativa C-sección durante el parto. De 169 mujeres puérperas sometidas a cesárea, 16 optaron por el procedimiento. Se encontró en este grupo de que la elección de cesárea prenatalmente influenciado por el poder médico; y en la trabajo de parto, fue motivado por la duración "prolongada" y el dolor de las contracciones próximos. Este estudio refuerza la importancia de la educación para la salud desde el embarazo y destacó la necesidad de fortalecer las políticas públicas que fortalezcan el potencial de las mujeres para tomar decisiones.

DESCRIPTORES: Educación en salud. Período de postparto. Cesárea. Políticas públicas. 


\section{INTRODUCTION}

Scientific advances, derived from the second half of the twentieth century, employed to assist pregnancy and childbirth, brought about significant changes in healthcare provided to women in Brazil by turning childbirth into a hospital and surgical procedure. ${ }^{1}$ Such innovations have significantly contributed to the growth of the medicalization of childbirth and to the strengthening of biomedical knowledge in juxtaposition to the humanized home and traditionally feminine knowledge used until then. ${ }^{2}$

In Brazil, the medicalization of childbirth contrasts with the recommendations of the World Health Organization (WHO) of an optimal rate of cesarean section between $10-15 \%$ and as minimum a number of interventions as possible in childbirth care. Medicalization has also contributed to increasing cesarean section rates: $32 \%$ in $1994 ; 38.9 \%$ in 2000; $46.5 \%$ in 2007; and $52 \%$ in $2010 .^{3-5}$

Despite the increase in the percentage of cesarean section in Brazil, initiatives and public policies have been consolidated in order to change the paradigm of childbirth care, such as the Program of Humanization in Prenatal and Birth, the National Policy for Integral Attention to Women's Health, the Pact to Reduce Maternal and Neonatal Mortality, the Baby Friendly Hospital Initiative, and the Cegonha Network. ${ }^{6}$

Another strategy to help reduce the high cesarean section rates are health promotion activities, among which are collective educational practices such as those conducted with groups of pregnant women. Within the context of Florianópolis at the Universidade Federal de Santa Catarina (UFSC), the extension project Group of Pregnant Women and Pregnant Couples is an alternative way to implement and consolidate the best practices recommended by Brazilian public health policies.

From this perspective, the Group of Pregnant Women and Pregnant Couples has, since 1996, aimed at sharing knowledge about the different types of childbirth, its indications and care actions. This group consists of an interactive, dynamic, and complex microenvironment, directed toward health promotion, humanized care, and autonomy of participants, providing changes in living conditions, changes of attitudes in the conduct of the birth process, and the development of good obstetric practices dedicated to a healthy lifestyle. It is a free, educational, and interdisciplinary extension project, directed toward pregnant women and their companions, coordinated by professors of the Department of Nursing, a childbirth educator, and professionals from the University Hospital of UFSC. It is also a space for research and teaching, which contributes to professional training, production, and sharing of new knowledge and practices. Each year, four groups of pregnant women get together, with the participation of 25 pregnant women and their companions, from the public or private sector. Eight weekly meetings are held, during the evening, at the training center of the University Hospital. As of August 2014, 72 groups have met, with the participation of 1,376 pregnant women and 810 companions, students from different courses, and health professionals. ${ }^{7}$

Throughout its existence, the group has consolidated a significant number of data with, however, few opportunities to analyze them. In view of the health policies aimed at reducing cesarean section rates in Brazil, participants in the group went through the data produced in order to, in light of this information and the resulting scientific papers, offer contributions to change the current paradigm of the medicalization of childbirth.

In recent years, it was noted that the number of women who choose natural childbirth has been higher than those who chose cesarean section. However, even with the advances and changes in patterns for assisting women, encouraging natural childbirth and reducing interventions in the birth process, it was found that over $30 \%$ of the women participating in the group still opted for surgery by their own choice or because they were influenced. The knowledge acquired did not suffice to combat the culture of cesarean section that has been built in these societies.

A research study entitled Nascer no Brasil, conducted with 23,940 women in 266 hospitals and 191 cities, pointed out that nearly $66 \%$ of the interviewees stated they would rather vaginal birth at the beginning of pregnancy. However, in the private sector only $14.6 \%$ succeeded in undergoing this procedure while, in the public sector $57 \%$ did. In the same study it was found that, at the end of pregnancy, one-third of women had changed their minds, choosing cesarean section; one-quarter had not yet decided on the type of birth; and 51.5\% underwent cesarean section to complete the childbirth process, of which $65.7 \%$ underwent cesarean section without going into labor. The research also concluded that women, regardless of the source of payment for the childbirth and of parity, are not supported or encouraged in their choice of vaginal birth at the end of pregnancy. ${ }^{8}$ This conclusion has aroused great concern about the reasons that lead women to choose cesarean section as an alterna- 
tive, and points to to the importance of identifying and researching the factors associated with the decision based on the type of birth.

From this perspective, in order to extend the state of the art and understand this phenomenon, this study puts the question: What are the determinants of women's preference for cesarean section? In answering this question, this study was intended to identify the determinants of women's preference for cesarean section.

\section{METHOD}

This is an exploratory, descriptive, documentary, and retrospective research study with a qualitative approach. Data from this study are part of the extension project of the database Group of Pregnant Women and Pregnant Couples of UFSC, which has documents dating from March of 1996 to June of 2013. The documents, manually and digitally recorded, include: registration of participants; statements from the groups of pregnant women and pregnant couples as well as reunions of parents and babies; evaluation of the activities; and terms of consent.

Data collection took place from December 2012 to July 2013. During this period, transcribed speeches of the postpartum women of the group were selected, in an activity promoted by the project, entitled Reunion of Parents and Babies, that occurs one month after the birth of the last baby of the women in the group.

Thus, reports of 448 women were arranged. Afterwards, the reports were classified into two groups: 1) reports of postpartum women who underwent cesarean section; and 2) reports of postpartum women who did not undergo cesarean section. Through this process, it was possible to identify the number of postpartum women who underwent cesarean section, corresponding to a total of 169 women (37.72\%). The value measured was lower than the national and state data released, and points out that most of the live births in Brazil (53.74\%) and Santa Catarina (58.88\%) involved surgery. ${ }^{9}$ This percentage was well above $15 \%$, according to the $\mathrm{WHO} .^{5}$

The 169 reports were reclassified, but this time the reasons that led postpartum women to choose cesarean section were identified. Hence, as a target of this research, 16 postpartum women who chose cesarean section were selected. Data analysis was conducted by means of a thematic analysis using the following steps: a) pre-analysis, in which the documents to be used for analysis were chosen, which made up the corpus; b) exploration of the material, which consisted of a classification process of text comprehension by setting up the themes that, grouped by common characteristics, gave rise to the thematic categories; and c) treatment and interpretation of the results obtained, by which data were analyzed based on theoretical grounds. ${ }^{10}$ The profile data were analyzed through simple statistics.

Ethical principles were observed, according to the recommendations of Resolution no. 466/12 of the National Health Council. ${ }^{11}$ The study was submitted to and approved by the Committee on Ethics in Research of UFSC under Opinion n.724.385. Participants signed a free and clarified consent form, and their anonymity was guaranteed by the replacement of their names with the letter " $\mathrm{P}$ " to denote "postpartum woman," followed by the ordinal number of each document.

\section{RESULTS AND DISCUSSION}

Data analyzed gave rise to the Choice for Cesarean Section category, with three subcategories: who chooses cesarean section; preference for cesarean section defined during prenatal care; and possibility to choose cesarean section during labor.

\section{Who chooses cesarean section?}

In this subcategory, we addressed the social and obstetric profile of women who choose cesarean section. Of all women who underwent cesarean section, $9.46 \%$ did so by their own choice. Considering this percentage, most who chose cesarean section were between 26 and 32 years of age $(52.94 \%)$. Of the total number, $61.17 \%$ were married and $58.82 \%$ had an undergraduate degree. Moreover, it was found that most were primiparous $(80 \%)$, had had prenatal care, and had given birth in a private institution $(55.29 \%)$.

The results pointed to the relation between preference for cesarean section and higher social and economic status (higher education and economic level). A contrasting study showed that most women, whatever their social and demographic profile, do not prefer cesarean section, even if they have undergone this procedure before, ${ }^{12-13}$ because about $70 \%$ to $80 \%$ of pregnant women, from both the public and private sector, prefer natural childbirth. ${ }^{14-15}$ Research completed in 2014 showed that $66 \%$ of women from a total of 23,940 participants preferred natural childbirth at the beginning of pregnancy; however, in the private sector, the proportion of preference for cesarean section was higher. At the end of pregnancy, the proportion of women who demonstrated a preference for cesar- 
ean section remained stable in the public sector, but reached values greater than $70 \%$ in the private sector. In this sector, in most cases, the decision was made by women by their own choice or together with the prenatal doctor. ${ }^{8}$ This situation may be better analyzed through the reports:

I said that I wanted a natural childbirth, but [...] I chose the cesarean section (P54).

[...] I wanted a natural childbirth, but I was no longer able to push, so I said that I wanted the cesarean section (P62).

In order to confirm the above, a study conducted in public and private hospitals in Brazil concluded that many women prefer natural childbirth. However, when analyzing the values related to the cesarean sections performed, we observed that the cesarean section rate was higher than the natural childbirths, corresponding to $70 \%$ in the private sector, of which $64 \%$ are planned. ${ }^{16}$ The same applied to education and marital status in primiparous women. Although the preference is not defined according to these factors, cesarean section rates are more noticeable when education level is higher and when women are married or live with their partner. ${ }^{17}$ Conception, however, may not be a predictive factor of the preference of women in the private sector for cesarean sections, despite the high cesarean section rates therein, but certainly the promptness to schedule this procedure contributes to this situation, as can be observed in the transcripts:

It was very easy, a scheduled cesarean section [...] (P66).

I felt sad; I really wanted a natural childbirth, but I scheduled the cesarean section for 39 weeks (P59).

The above confirms the culture of cesarean section in Brazil, and shows that, although women prefer natural childbirth regardless of their social profile, most end up choosing cesarean section, whether during prenatal care or labor. This situation occurs due to several technical factors or the adoption of interventional procedures that feed the cesarean phenomenon. Among these factors, we consider: the use of methods of diagnosis of fetal well-being that, in turn, increase the criteria for the indication of cesarean section; better results shown by the indicators of maternal and fetal morbidity and mortality; improved surgical techniques; advances in blood therapy and antibiotic therapy; ${ }^{18}$ and, above all, the presence of doctors in this context. ${ }^{19}$ Influences from culture and family also contribute to women's preference for cesarean section.

Such factors are considered during pregnancy or labor and, therefore, will be further explored in the next subcategories.

\section{Preference for cesarean section defined during prenatal care}

The results of this study showed that not all women justified their choice of cesarean section during prenatal care. Among those who did, the main explanations given for their preference for cesarean section during prenatal care were related to their clinical history, that is, advanced age and the wish to undergo a tubal ligation during cesarean section, as can be observed in the transcripts:

I am 40 years old. Age was one of the reasons for me to choose cesarean section, because the doctor who was watching me had told me not to choose natural childbirth under any circumstances. I scheduled the cesarean section. The only problem was that he broke two of my ribs, it was very painful. The doctor said it was an accident, because his elbow slipped (P65).

I underwent a scheduled cesarean section and tubal ligation; the surgery was conducted at a health center (P46).

Although the participants have justified their choice for cesarean section, the reasons given - age and tubal ligation - which were also confirmed in other research, ${ }^{8,14}$ are not in accordance with the literature as absolute indications for cesarean section. The ligation, an irreversible method, can only be performed 60 days after the childbirth, with the consent of the couple, except in cases of previous successive cesarean sections or those in which exposure to another surgical procedure poses a risk to the woman's life. ${ }^{20-21}$

Some women establish complicity with their doctor, turning the responsibility over to him in relation to their health due to their incapacity to decide, the comfort and convenience of the date scheduled for the organization of their daily family life, or even through fear of pain and the risks that may occur.

I scheduled the cesarean section during prenatal care. After 39 weeks contractions started coming. I sought the doctor and we decided for the cesarean section, because I could go into labor at any time (P51).

Thus, professionals empower themselves, take on the role that society expects from them and that they consider the most correct, because they believe that this procedure ensures a favorable outcome for women and their babies. This behavior is put into question in a research study on the mental representations of women about the childbirth. The authors questioned whether doctors, when they suggest a cesarean section, have personal interests only or indicate the technique over which they have domain and that, for them, is the most appropriate at the moment. 
In this sense, they reinforce the importance of considering the cultural issue, the responsibility that is granted to the doctors by society, and their emotional involvement with the pregnant couple. ${ }^{18}$ This matter points to the importance of reflecting on the training of these professionals and on the socially determined cultural aspects that influence women's choices in relation the type of childbirth.

On the other hand, the results also showed that the motivation to undergo a cesarean section was based not only on scientific evidence, the desire of women, or the role socially granted to the doctors, but on the convenience of the doctors, as shown below:

cesarean section was decided during prenatal care. I did not even go into labor. Cesarean section was scheduled for the morning, but as the doctor had a congress to attend, it could not be performed at this time, and it was scheduled for the night (P61).

Findings revealed that women's preference for cesarean sections, defined during prenatal care, is not based on scientific criteria, and can derive from the clinical insecurity of obstetricians and their incompetence to perform natural childbirths, because a significant number of professionals were trained within a technocratic, biologistic model focused on technique/intervention, and not on the patient and their active involvement. Moreover, we may also consider the lack of time available to monitor the childbirth, due to their working agenda. There is even the cost-benefit ratio of performing a childbirth that has no predictability as to its length of time and when it will be concluded, whereas with a cesarean section professionals can determine the time and day of its performance, according to their availability and convenience.

Authors confirmed the above, stating that the justification is incorrect, and the lack of justification for cesarean sections can be legitimated by the behavior adopted by doctors, based on social relations, economic interests, and convenience, which significantly contributes to the banalization of cesarean sections, ${ }^{19}$ in particular elective ones. ${ }^{22}$ The other justification is to intervene in order to have more safety; however, the literature shows that the risks and complications are higher in case of cesarean sections. ${ }^{14}$

The use of technological procedures may also reaffirm the convenience. Professionals use technical information that is not indicative of a cesarean section in order to justify performing the procedure, because women are not aware of this and are experiencing a delicate, unpredictable moment when they are subject to risks that make them fragile and unable to decide, as it can be observed below: [...] I have always wanted to undergo a cesarean section, but after having participated in the group [of pregnant women and pregnant couples], I have been even thinking of having a natural childbirth. Then I talked to my doctor. And we noticed that the baby was too big. The ultrasound technician suggested a cesarean section, and told me that the baby would not come down, because he/she was too big. So, he/she was born by a cesarean section at 3,755 Kg (P66).

The use of technologies for the evaluation of fetal wellbeing is becoming a trend in healthcare organizations, so that they promote and justify the indications for cesarean sections. ${ }^{18}$ Such innovations contribute to the early diagnosis of several dystocias that can hinder the feasibility of a natural childbirth.

The fact is that analysis of the results of the exams and indications for this procedure are made by doctors together with women and their companions, who often feel intimidated by the medical authority, ${ }^{23}$ and accept the conducts employed without question. It is noteworthy that, in addition to medical authority and influence, this situation is due to a lack of information about the indications and risks that should be explained to women during prenatal care, as well as the socially determined belief that a cesarean section is safer, which is confirmed by the literature. ${ }^{18}$

Participation in the Group of Pregnant Women and Pregnant Couples was also mentioned, in this case as a factor questioning the outcome previously planned. The quote above shows that women, even those participating in discussions that address the advantages and disadvantages of cesarean sections, end up giving more value to the doctor's judgment with regard to the choice of the desired type of childbirth. This occurs because the choice of a cesarean section is never a choice made only by women. That is, it is a choice shared between women/their families and the doctor, because this professional is the one who assists women throughout the course of their pregnancy, who has their trust, and is responsible for recommending and conducting the type of childbirth. The technical arguments of these professionals and their orientation have a significant impact on the choice of the type of childbirth, specifically on the choice of cesarean section, rendering the initiatives toward natural childbirth ineffective. ${ }^{23}$

\section{Possibility to choose cesarean section during labor}

According to the transcripts, the preference for cesarean section during labor was mainly mo- 
tivated by the fear of pain caused by contractions and the prolonged duration of this period.

I had contractions and was afraid to feel pain during natural childbirth (P49).

I was groaning in pain. [...] Then he [the doctor] advised me to undergo a cesarean section, arguing that I would not have strength to undergo a natural childbirth (P61).

[...] the doctor said that, in the state in which I was, I would have the baby only at dawn. As the labor was being very tiresome and painful, I chose the cesarean section (P54).

I underwent cesarean section because I wanted to. I did not want to wait for labor to begin. I felt contractions all night long. The baby came down, I had dilation, but I underwent a cesarean section (P26).

The transcripts describe natural childbirth as painful and of prolonged duration, and cesarean section as a procedure that provides convenience, speed, and freedom from pain. A study developed with the purpose of analyzing the perspectives of primiparous women about the pain during natural childbirth and its relation with the prenatal care and social and cultural context, emphasized that obstetricians, in addition to maintaining the biomedical and interventional model of assistance, emphasize cesarean section as a solution to the pain caused by natural childbirth, and introduce the idea that women are not to blame for the pain, but they are victims of their own nature. ${ }^{24}$

Misperceptions about the exemption from pain during and after a surgical procedure are questionable, because many women are not informed as to the duration of labor and other factors related to the physiology of natural childbirth, as well as about the postoperative pain inherent in surgical procedures such as a cesarean section. ${ }^{25}$ In addition to misinformation, unnecessary interventions during labor, and obstetric violence turn what would be a normal event in a dehumanizing procedure, and further increase painful sensations and fears, which contribute to the acceptance of and request for cesarean section.

The process from conception to childbirth is a period in which women and their families share different experiences and expectations that are socially and culturally crystallized, and that may reinforce fears and negative feelings about childbirth. Fear of being unable to bear the pain, of dying, of being dilacerated, as well as the feeling of not being able to give birth, are frequent anguishes during labor, and make women more vulnerable to medical interventions during this period. ${ }^{26}$ For this reason, it is important to observe the context in which postpartum women exist and encourage physical, psychological, and educational support for those involved. One of the ways to provide emotional support and increase the chances of a natural childbirth, free of interventions, is to have the participation of fathers and/or companions during the process of parturition. ${ }^{27-28}$

Another strategy to give support to women and their families at this time is to have the assistance of an obstetric nurse in the process, with the aim of understanding the emotions of those involved, conveying confidence, encouraging women, and showing them that they are able to endure painful sensations during labor, therefore ensuring lower rates of cesarean sections. ${ }^{19,29}$ In addition to the aspects related to emotional support, nurses can use non-pharmacological methods of pain relief, such as the use of the Swiss ball, a therapeutic bath, massage, among others. Such methods are based on scientific evidence and knowledge that take the medicine and epidemiology into account, and organize professional performance in the labor process. ${ }^{30}$

In this sense, the obstetric nurse is essential to support women in the evolution of the labor and birth process, and to increase their knowledge about this moment, thus reducing external influences that lead to a birth with intervention. The importance of this professional in the planning and implementation of interdisciplinary educational practices, in particular the group of pregnant women, is also noteworthy.

\section{FINAL CONSIDERATIONS}

This study allowed us to identify the determinants of women's preference for caesarean section. During prenatal care, the determinants advanced age and desire to perform a tubal ligation during cesarean section. During labor, the fear of pain, prolonged duration of the parturition process, misinformation, convenience, as well as recommendation of the procedure by the doctor for the safety of the child and the interventional power of this professional were the factors that motivated women to choose cesarean section.

It was found that the influence of the professionals who follow the prenatal care and orientations received during this period are decisive in choosing the type of childbirth. Hence, it becomes necessary to share with pregnant women and their companions information about the physiology of labor, non-pharmacological methods of pain relief, and the advantages, disadvantages, and risks of the different ty pes of childbirth, as well as to share successful experiences about natural childbirth. It 
is also essential to reflect on and discuss this matter with health professionals, so this moment as experienced by women and their families is not handled as a medical issue.

It is important to review the training of students in the health arena, in order to restore the role of women in the birth process, providing opportunities for them to decide on the type of childbirth based on consistent information and scientific evidence. Moreover, it is important to discuss beliefs that have been passed down from generation to generation in relation to natural childbirth and cesarean section, and that reinforce the idea that a surgical procedure has fewer risks and complications, which is not true according to the scientific evidence. Disclosing such evidence to the media may contribute to change this biologistic and interventional model that is still in force.

Considering that women of a higher cultural and economic level, assisted in private institutions, are those who have a preference for cesarean section, it becomes necessary to develop educational practices with this group of women and inform them of the risks and complications of cesarean section for them and their babies when there is not an accurate indication for the procedure. The advantages and disadvantages of the different types of childbirth should also be provided, including that cesarean section should be performed for the wellbeing and safety of the mother-baby binomial. Having been informed, these women may disseminate information and encourage natural childbirth on social networks and in their daily spaces.

The subcategory Preference for cesarean section defined during labor highlights the lack of support and information for postpartum women, which is reflected in their perception of the painful sensation caused by contractions and the prolonged duration of labor. Such results allow us to observe how vulnerable these postpartum women become, and how the obstetric nurse may contribute to the emotional, educational, and physical support during this unique and complex moment in the life of women, their fetuses, and their families.

This study reinforced the importance of health education, especially of the use of the Group of Pregnant Women and Pregnant Couples as a tool to contribute to a quality prenatal care and to strengthen the potential of women to make choices in the conduct of the birth process. It points out that orientations received from professionals during prenatal visits and influence from family have a significant importance in the choice of the type of childbirth. In view of this, participation of the family, especially the companion, providing assistance during the birth process is essential.

The research also allowed us to identify the need to consolidate public policies on this issue and the need to qualify and train health professionals working in obstetrics on the best practices in labor and childbirth, as well as to review the training of health professionals that is currently focused more on technology than on the person who seeks the service.

Finally, because this study was restricted to the context of a single group of pregnant women, which limits the generalizability of the results achieved, we suggest that further research be conducted in order to broaden the understanding of the preferences of women in other contexts.

\section{REFERENCES}

1. Leão MRC, Riesco MLG, Schneck CA, Angelo M. Reflexões sobre o excesso de cesarianas no Brasil e a autonomia das mulheres. Ciênc Saúde Coletiva. 2013 Ago; 18(8):2395-400.

2. Cardoso JE, Barbosa RHS. O desencontro entre o desejo e a realidade: a "indústria" da cesariana entre mulheres de camadas médias no Rio de Janeiro, Brasil. Physis. 2012; 22(1):35-52.

3. Patah LEM, Malik AM. Modelos de assistência ao parto e taxa de cesárea em diferentes países. Rev Saúde Pública. 2011 Fev; 45(1):185-94.

4. Porto AMF, Amorim MMR, Souza ASR. Assistência ao primeiro período do trabalho de parto baseada em evidências. Femina. 2010 Out; 38(10):527-37.

5. Ministério da Saúde (BR). Secretaria de Vigilância em Saúde. As cesarianas no Brasil: situação do ano de 2010 - tendências e perspectivas. Brasília (DF): MS; 2011.

6. Ministério da Saúde (BR). Portaria n. 1.459, de 24 de junho de 2011. Institui, no âmbito do sistema único de saúde - SUS, a Rede Cegonha. Brasília (DF): MS; 2011.

7. Zampieri MFM, Gregório VRP, Custódio ZAO, Regis MI, Brasil C. Processo educativo com gestantes e casais grávidos: possibilidade para transformação e reflexão da realidade. Texto Contexto Enferm. 2010 Out-Dez; 19(4):719-27.

8. Domingues RMSM, Dias MAB, Pereira MN, Torres JA, D'Orsi E, Pereira APE, et al. Processo de decisão pelo tipo de parto no Brasil: da preferência inicial das mulheres à via de parto final. Cad Saúde Pública [online]. 2014 [acesso 2014 Set 18]; 30(Sup.1):. Disponível em: http:/ / www.scielo.br/scielo. php?script=sci_abstract\&pid=S0102-311X20140013 00017\&lng=en\&nrm=iso\&tlng=pt 
9. Ministério da Saúde (BR). Informações de Saúde. DATASUS 2011 [online]. Brasília (DF): MS; [acesso 2013 Set 14]. Disponível em: http:/ / tabnet.datasus. gov.br/cgi/tabcgi.exe?sinasc/cnv/nvuf.def

10. Minayo MCS. O desafio do conhecimento. São Paulo (SP): Hucitec; Abrasco; 2010.

11. Ministério da Saúde (BR). Conselho Nacional de Saúde Resolução no ${ }^{\circ}$ 466, de 12 de dezembro de 2012. Diretrizes e normas regulamentadoras de pesquisas envolvendo seres humanos. DOU n. 12, seção1, p.13 Brasília (DF): MS; 2013.

12. Dias MAB, Domingues RMSM, Pereira APE, Fonseca SC, Gama SGN, Theme Filha MM, et al. Trajetória das mulheres na definição pelo parto cesáreo: estudo de caso em duas unidades do sistema de saúde suplementar do estado do Rio de Janeiro. Ciênc Saúde Coletiva. 2008 Set-Out; 13(5):1521-34.

13. Sass N, Hwang SM. Dados epidemiológicos, evidências e reflexões sobre a indicação de cesariana no Brasil. Diagn Tratamento. 2009 Out-Dez; 14(4):133-7.

14. Faisal-Cury A, Menezes PR. Fatores associados à preferência por cesariana. Rev Saúde Pública. 2006 Abr; 40(2):226-32.

15. Potter JE, Berquó E, Formiga MCC. Unwanted caesarean sections among public and private patients in Brazil: prospective study. Br Med J. 2001 Nov; 323(7322):1155-8.

16. Potter JE, Hopkins K, Faúndes A, Perpétuo I. Women's autonomy and scheduled cesarean sections in Brazil: a cautionary tale. Birth. 2008 Mar; 35(1):33-40.

17. Oliveira DR, Cruz MKP. Estudo das indicações de parto cesáreo em primigestas no município de Barbalha-Ceará. Rev Rene. 2010 Jul-Set; 11(3):114-21.

18. Pereira RR, Franco SC, Baldin N. Representações sociais e decisões das gestantes sobre a parturição: protagonismo das mulheres. Saúde Soc. 2011 Jul-Set; 20(3):579-89.

19. Tesser CD, Knobel R, Rigon T, Bavaresco GZ. Os médicos e o excesso de cesárias no Brasil. Saúde Transf Soc. 2011; 2(3):4-12.

20. Soalheiro LC. Fatores associados à preferência por cesariana em uma amostra representativa de primíparas na Região Sul do Brasil [dissertação]. Rio de Janeiro (RJ): Fundação Osvaldo Cruz-FIOCRUZ; 2012.
21. Berquó E, Cavenaghi S. Direitos reprodutivos de mulheres e homens face à nova legislação brasileira sobre esterilização voluntária. Cad Saúde Pública [online]. 2003 Jan [acesso 2014 Set 19]; 19(Suppl2):. Disponível em: http:/ / www.scielo.br/scielo.php?script $=$ sci_arttext\&pid $=S 0102-311$ X2003000800025

22. Ferrari J. A autonomia da gestante e o direito pela cesariana a pedido. Rev Bioética. 2009; 17(3):473-95.

23. Pires D, Fertonani HP, Conill EM, Matos TA, Cordova FP, Mazur CS. A influência da assistência profissional em saúde na escolha do tipo de parto: um olhar sócio antropológico na saúde suplementar brasileira. Rev Bras Saúde Mater Infant. 2010. AbrJun; 10(2):191-7.

24. Almeida NAM, Medeiros M, Souza MR. Perspectivas de dor do parto normal de primigestas no período pré-natal. Texto Contexto Enferm [online]. 2012 OutDez [acesso 2014 Ago 8]; 21(4):819-27. Disponível em: http://www.scielo.br/pdf/tce/v21n4/12.pdf

25. Sell SE, Beresford PC, Dias HHZR, Garcia ORZ, Santos EKA. Olhares e saberes: vivências de puérperas e equipe de enfermagem frente à dor pós-cesariana. Texto Contexto Enferm [online]. 2012 Out-Dez [acesso 2014 Jul 9]; 21(4):766-74. Disponível em: http://www.scielo.br/pdf/tce/v21n4/06.pdf

26. Sarmento R, Setúbal MSV. Abordagem psicológica em obstetrícia: aspetos emocionais da gravidez, parto e puerpério. Rev Ciênc Méd. 2003 Jul-Set; 12(3):261-8.

27. Perdomini FRI, Bonilha ALL. A participação do pai como acompanhante da mulher no parto. Texto Contexto Enferm. 2011 Jul-Set; 20(3):445-52.

28. Bruggemann OM, Oliveira ME, Martins HEL, Alves MC, Gayeski ME. A inserção do acompanhante de parto nos serviços públicos de saúde de Santa Catarina, Brasil. Esc Anna Nery Rev Enferm. 2013 Jul-Set; 17(3):432-8.

29. Reis SP, Meincke SMK, Bielemann VLM, Carraro TE, Lopes CV. Percepção das puérperas quanto ao cuidado prestado pela equipe de saúde durante o trabalho de parto. Ciênc Cuid Saúde [online]. 2008 [acesso 2014 Jul 9]; 7(Suppl 2). Disponível em: http://www.periodicos.uem.br/ojs/index.php/ CiencCuidSaude/article/viewFile/20938/pdf

30. Gayeski ME, Brüggemann OM. Métodos não farmacológicos para alívio da dor no Trabalho de parto: uma revisão sistemática. Texto Contexto Enferm. 2010 Out-Dez; 19(4):774-82. 